\title{
Pelatihan Komputer Microsoft Office dan Media Pembelajaran Animasi untuk Meningkatkan Kompetensi Guru SDIT Al Muhajirin
}

\author{
Endi Permata*1, Yus Rama Denny $\mathbf{M}^{2}$, Irwanto3 ${ }^{3}$, Mohammad Fatkhurrokhman ${ }^{4}$ \\ 1,3,4Program Studi Pendidikan Vokasional Teknik Elektro, Fakultas Keguruan dan Ilmu Pendidikan, \\ Universitas Sultan Ageng Tirtayasa \\ ${ }^{2}$ Program Studi Pendidikan Fisika, Fakultas Keguruan dan Ilmu Pendidikan, Universitas Sultan Ageng \\ Tirtayasa \\ *e-mail: endipermata@untirta.ac.id ${ }^{1}$,yusramadenny@untirta.ac.id ${ }^{2}$,irwanto.ir@untirta.ac.id ${ }^{3}$ \\ fatkhur0404@untirta.ac.id ${ }^{4}$
}

\begin{abstract}
This community service activity aims to increase the competence of information and communication technology (ICT) through Microsoft Office computer training and animation learning media at the Al Muhajirin Integrated Islämic Elementary School, Cilegon, Banten. The output of this program has an impact on the creation of teachers who are skilled in using technology in learning, trained teachers who are able to use technology especially Microsoft Office and learning animation media. In this training, DIT Al Muhajirin Cilegon Banten teachers were trained on Microsoft office and the theory and principles of animation as a learning medium. Furthermore, the training continued with intensive mentoring of the SDIT Al Muhajirin Cilegon Banten teacher to choose themes and practices for making learning animations. With the training held at SDIT Al Muhajirin Cilegon Banten, this primary school teacher who became a participant in community service has achieved this understanding of the benefits of sustainable professional development in teacher performance assessment. Teachers are able to master how to make animation media for learning using PowerPoint Microsoft Teachers at SDIT Al Muhajirin Cilegon Banten who are community service participants are trained to understand the features and functions in Microsoft PowerPoint which are used for making animation media in learning. From the results of community service activities carried out at SDIT Al-Muhajirin Cilegon Banten, it can be concluded that the assessment of the ability of participants on average is around $84.15 \%$ and have mastered and understood Microsoft office materials and learning animations.
\end{abstract}

Keywords: Information and Communication Technology, Microsoft Office, Animation Media, Learning

\begin{abstract}
Abstrak
Kegiatan pengabdian pada masyarakat ini bertujuan untuk mengadakan untuk meningkatkan kompetensi teknologi informasi dan komunikasi (TIK) melalui pelatihan komputer Microsoft Office dan media pembelajaran animasi di Sekolah Dasar Islam Terpadu Al Muhajirin Cilegon Banten. Luaran program ini berdampak pada terciptanya guru yang terampil mengunakan teknologi dalam pembelajaran, terlatihnya guru yang mampu mengunakan alat teknologi secara tepat terutama tentang optimalisasi Microsoft Office dan media pembelajaran animasi , dan diharapkan para guru yang mengikuti pelatihan ini mendapatkan banyak pengetahuan tentang menggunakan Microsoft office serta media pembelajaran. Pada pelatihan ini guru SDIT Al Muhajirin Cilegon Banten dilatih tentang Microsoft office serta teori dan prinsipprinsip Animasi sebagai media pembelajaran. Selanjutnya pelatihan berlanjut dengan pendampingan secara intensif guru SDIT Al Muhajirin Cilegon Banten tersebut untuk memilih tema dan praktik membuat animasi pembelajaran. Dengan pelatihan yang diselenggarakan di SDIT Al Muhajirin Cilegon Banten ini telah dicapai guru sekolah dasar yang menjadi peserta pengabdian kepada masyarakat ini memahami manfaat pengembangan keprofesian berkelanjutan dalam penilaian prestasi kinerja guru. Guru mampu menguasai cara pembuatan media animasi untuk pembelajaran menggunakan Microsort PowerPoint. Para guru di SDIT Al Muhajirin Cilegon Banten yang menjadi peserta pengabdian dilatih untuk memahami fitur dan fungsi dalam Microsoft PowerPoint yang digunakan untuk pembuatan media animasi dalam pembelajaran. Dari hasil kegiatan pengabdian kepada masyarakat yang dilakukan di SDIT Al-Muhajirin Cilegon Banten dapat disimpulkan bahwa penilaian kemampuan peserta rata-rata sekitar 84,15\% dan telah menguasai dan memahami materi Microsoft office dan animasi pembelajaran yang disampaikan dalam kegiatan pengabdian masyarakat.
\end{abstract}

Kata kunci: Teknologi Informasi Dan Komunikasi, Microsoft Office, Media Animasi, Pembelajaran 


\section{PENDAHULUAN}

Animasi pada saat ini banyak dimanfaatkan untuk berbagai kebutuhan dalam berbagai kegiatan baik untuk kegiatan yang bersifat santai maupun serius, dari mulai fungsi yang utama sampai fungsi tambahan atau hiasan. Animasi dibangun berdasarkan manfaatnya sebagai media yang digunakan untuk berbagai keperluan selain animasi digunakan dalam hiburan dan film animasi juga memiliki manfaat dalam media pembelajaran.Media Animasi dalam pembelajaran bertujuan untuk memaksimalkan efek visual dan memberikan interaksi berkelanjutan sehingga pemahaman bahan ajar meningkat. Media Animasi dalam pembelajaran memiliki kemampuan untuk dapat memaparkan sesuatu yang rumit atau komplek untuk dijelaskan dengan hanya gambar dan kata-kata saja. Dengan kemampuan ini maka Media animasi dapat digunakan untuk menjelaskan suatu materi yang secara nyata tidak dapat terlihat oleh mata, dengan cara melakukan visualisasi maka materi yang dijelaskan dapat tergambarkan.

Media pembelajaran telah terbukti berperan aktif untuk meningkatkan motivasi dan intelektual siswa dalam proses pembelajaran. Maka dari itu pengembangan media pembelajaran diperlukan sebagai penunjang pembelajaran sesuai empat rekomendasi pilar yang dicetuskan oleh UNESCO yaitu 1) learning to know (belajar untuk mengetahui), 2) learning to do (belajar melakukan atau mengerjakan), 3) learning to live together (belajar untuk hidup bersama), 4) learning to be (belajar untuk mengembangkan diri sendiri) (Hendra, 2016). Dengan semakin pesatnya perkembangan teknologi di berbagai bidang maka dunia pendidikan harus menyesuaikan diri mengikuti perkembangan. Guru merupakan salah satu bagian yang terpenting dalam proses belajar mengajar di kelas, sehingga dibutuhkan sosok guru yang inspiratif, kreatif, inovatif dan mampu memanfaatkan teknologi informasi dan komunikasi dalam proses pembelajaran bukan guru yang gagap terhadap teknologi (gaptek). Sebagai pendidik profesional guru memiliki tugas utama mendidik, mengajar, membimbing, mengarahkan, melatih, menilai, dan melaksanakan evaluasi peserta didik pada pendidikan anak usia dini jalur pendidikan formal, pendidikan dasar, dan pendidikan menengah. Karena sebagai pendidik profesional maka sumber penghasilan utama adalah dari tugas pekerjaannya sebagai Guru, dalam memenuhi kebutuhan hidup. Oleh karena itu Guru harus memiliki keahlian, kemahiran, atau kecakapan pemanfaatan teknologi. Perkembangan teknologi informasi memungkinkan guru dapat membuat media pembelajaran sendiri karena saat ini banyak komputer berbasis grafis yang memudahkan pembuatan animasi. Animasi untuk manfaat pendidikan dapat dikembangkan sesuai kebutuhan dan tingkat belajar anak. Guru dapat menentukan jenis animasi apa saja yang sesuai untuk pembelajaran yang diajarkan di sekolah yaitu mata pelajaran Matematika, Bahasa Indonesia, Bahasa Inggris, IPA, IPS, PAI ataupun PKN.

Berdasarkan observasi dan wawancara dengan kepala sekolah, wakil kepala sekolah dan beberapa orang guru, permasalahan yang terjadi di Sekolah Dasar Islam Terpadu Al Muhajirin Kota Cilegon Provinsi Banten salah satunya masih banyak guru yang belum variatif mengunakan teknologi dalam kegiatan belajar mengajar dan pendekatan pembelajaran yang digunakan masih statis bahkan belum sesuai dengan yang diharapkan. Hal ini dikarenakan sumber daya manusia (SDM) guru yang terdapat di SD IT Al Muhajirin belum sepenuhnya mampu memanfaatkan teknologi informasi secara baik. Ditambah lagi jarangnya pelatihan-pelatihan yang diikuti guruguru mengenai keharusan mengunakan teknologi informasi secara variatif. Hal ini menyebabkan guru belum mampu inovatif mengunakan teknologi dalam kegiatan belajar mengajar.

Solusi yang ditawarkan untuk permasalahan tersebut adalah pelatihan komputer Microsoft Office serta animasi melalui in house traning (IHT) di SD IT Al Muhajirin. IHT mengenai pelatihan komputer Microsoft Office dilaksanakan di ruang perpustakaan dan laboratorium komputer SD IT Al Muhajirin dan diikuti oleh seluruh guru dengan harapan mengahasilkan guru yang mampu mengunakan teknologi secara variatif dalam pembelajaran dan tepat dalam pengunaan pendekatan pembelajaran. Dengan memanfaatkan media grafis oleh para guru di SD IT Al Muhajirin mengembangkan kompetensi para guru dalam mengajar menggunakan animasi komputer yang mendeskripsikan konten pembelajaran secara dinamis, misalnya pemanfaatan PowerPoint untuk mengembangkan dengan animasi yang sederhana dan 
mudah. Jika digunakan dengan tepat, bahkan perangkat lunak sederhana ini dapat menghasilkan animasi pendidikan yang efektif dan interaktif.

Menurut Elliot (2017) bahwa terdapat tiga pengetahuan yang diperlukan secara mendasar untuk menjadi seorang guru (pengajar), meliputi: (1) Theaching (Pedagogical) Knowledge yaitu bagaimana menyajikan materi ajar yang terbaik. Hal ini berkaitan dengan pengelolaan kelas, teknik instruksional, beberapa mengacu pada pengetahuanpedagogy. (2) Subject Matter Knowledge yaitu mengacu pada tata cara dalam mengorganisasi, strategi membuat formula dalam menyampaikan isi, apakah melalui cerita, bimbingan, menggunakan teks, komputer, media atau lembaran kerja. (3) Teaching Subject Matter Knowledge yaitu bagaimana materi ajar tersebut dapat dipahami oleh siswa. Mengacu pada prinsip-prinsip dan strategi yang diterapkan pada materi tertentu.

Guru merupakan kunci dalam peningkatan mutu pendidikan dan mereka berada di titik sentral dari setiap usaha reformasi pendidikan yang diarahkan pada perubahan-perubahan kualitatif. Berdasarkan penjelasan di atas maka dapat diketahui bahwa seorang pengajar perlu memiliki kemampuan untuk membuat media pembelajaran berbasis ICT. Media belajar berupa animasi dapat menampilkan perubahan yang terjadi, dan tepat untuk digunakan untuk pengajaran siswa Sekolah Dasar yang lebih cenderung adalah sebagai siswa pembelajar visual. Pada saat ini dalam pembuatan media pembelajaran multimedia berbasis teknologi informasi dan komunikasi (TIK) belum berkembang dengan optimal di Indonesia. Salah satu kendala pengembangan media pembelajaran multimedia adalah kurang dikuasainya teknologi pengembangan media pembelejaran multimedia berbasis TIK oleh para pengajar, sehingga pengembangan materi pembelajaran multimedia berbasis TIK kurang optimal (Setiawan \& Purnomo, 2016). Proses pembelajaran di sekolah hendaknya disertai dengan media pembelajaran.

Media pembelajaran yang paling banyak berkembang pada saat ini yaitu media pembelajaran berbasis komputer atau yang dikenal dengan nama multimedia interaktif. Salah satu contoh media pembelajaran berbasis komputer yang paling sederhana dan mudah untuk dibuat guru adalah media pembelajaran berbasis Powerpoint (Ardiansah and Miftakhi, 2019). Microsoft powerpoint merupakan aplikasi software yang dapat digunakan untuk menyampaikan materi berupa tulisan, gambar bentuk, foto, aneka warna dan jenis tulisan, fitur hyperlink, audio, video, dan animasi. Powerpoint merupakan media yang digunakan untuk menyampaikan poinpoin pokok dari materi yang kita sampaikan dengan fiturfitur yang menarik (Nurhidayati, 2019). Hanya ada satu dua guru yang pernah menggunakan namun belum memanfaatkan secara optimal fitur-fitur atau menu yang tersedia dalam program tersebut misal penggunaan gambar yang bergerak, memasukkan animasi, dan bahkan film.

Hal ini tentu, membuat suasana belajar kurang interaktif dan cenderung membosankan karena kurang memotivasi peserta didik dalam menerima pembelajaran. Alasan yang disampaikan oleh guru adalah karena mereka belum menguasai fitur-fitur yang ada pada program Microsoft Powerpoint (Poerwanti and Mahfud, 2018). Selain karena sumber daya manusia yang menguasai program ini masih sangat terbatas, ketersediaan lembaga lembaga kursus dan pelatihannya sangat langka (Ainin, Ahsanuddin, \& Asrori, 2019). Dalam penerapannya microsoft powerpoint dapat membantu pengajar dalam menyiapkan presentasi bahan ajar kepada siswa-siswi (Rusli, Winarso, \& Putri, 2020).

\section{METODE}

Pelaksanakan pada pengabdian masyarakat yang dilakukan oleh Program studi Pendidikan Fisika dan Program studi Pendidikan Vokasional Teknik Elektro Fakultas Keguruan dan Ilmu Pendidikan Universitas Sultan Ageng Tirtayasa ini meliputi tahap-tahap pertemuan yang dilakukan secara terstruktur dan berkelanjutan. Sasaran kegiatan ini adalah para guru SDIT Al Muhajirin Cilegon Banten berjumlah 32 orang. Lokasi kegiatan pengabdian kepada 
masyarakat ini adalah SDIT Al Muhajirin Cilegon Banten, dengan jumlah guru dan staf yang mengikuti kegiatan ini sebanyak 32 peserta yang dilaksanakan selama 3 hari di ruangan sekolah.

Metode yang digunakan adalah pelatihan, pengajarannya dengan memberikan contoh dasar secara teori dan praktek kepada peserta diiringi dengan praktek langsung peserta dalam mengikuti pelatihan ini. Hasil penilaian kemampuan peserta yaitu dengan cara melihat langsung hasil praktek yang dilakukan peserta oleh tim pengabdian kepada masyarakat. Penilaian kemampuan pesertra berdasarkan target yang ditawarkan dari kegiatan ini adalah melakukan pelatihan meningkatkan kemampuan guru dan staf dalam menyajikan presentasi intraktif melalui media microsoft powerpoint.

Adapun uraian tahap kegiatan yang dilaksanakan dalam pengabdian kepada masyarakat adalah sebagai berikut:

1) Tahap I (Tahap Pengenalan Program Pelatihan)

Tahap Pertama yang dilakukan adalah pendekatan secara edukatif tentang kebutuhankebutuhan peningkatan kualitas sekolah dengan kepala Sekolah Dasar Islam Terpadu Al Muhajirin melalui wawancara dan observasi atau pengamatan langsung keadaan sekolah. Kemudian dilanjut dengan dengan penyampaian materi:

a. Pengenalan arsitektur komputer

b. Pengenalan operating system (OS)

c. Pengenalan Microsoft Office terutama Microsoft Power Point dan penjelasan singkat tentang fungsi yang ada di Microsoft Power Point.

Penyampaian materi tersebut menggunakan metode diskusi dua arah, Tanya jawab, penugasan, dan diakhiri praktek yang dilaksanakan oleh peserta pelatihan, yang seperti di tunjukkan pada Gambar 1 di bawah ini.

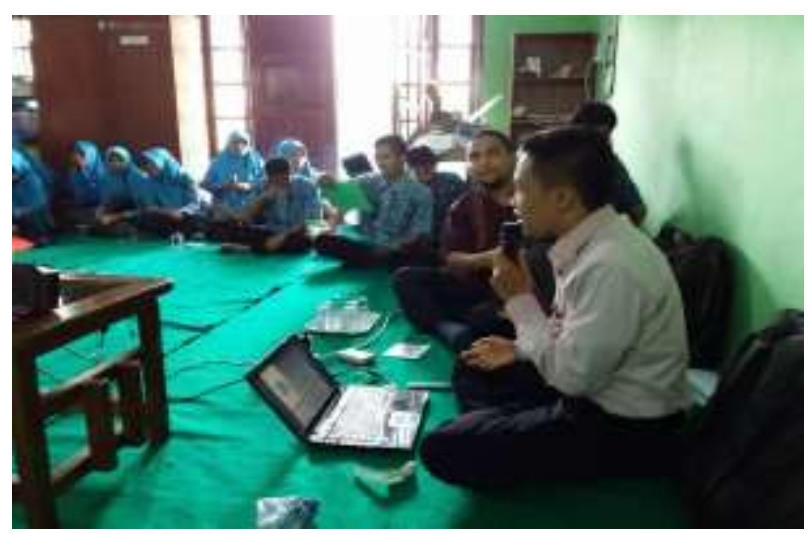

Gambar 1. Pengenalan arsitektur computer dan Microsoft office dengan metode Diskusi dua arah

2) Tahap II (Workshop)

Pada tahap ini dilaksanakan workshop/praktik pembuatan animasi menggunakan Microsoft PowerPoint. Workshop diawali dengan tutorial awal kepada para guru-guru mengenai perangkat lunak yang digunakan untuk pembuatan animasi yang digunakan dalam pelatihan ini. Peserta diajari dan dilatih yaitu cara membuka program yang ada, membuat file baru dari template atau dari blank document. Akan diajarkan juga cara menambahkan slide baru dan menyisipkan slide ditengah-tengah materi presentasi. Para peserta workhop ini diharapkan mampu memahami segala fungsi toolbar dan menu bar yang ada dalam Microsoft office PowerPoint seperti yang ditunjukkan pada Gambar 2 di bawah ini. 


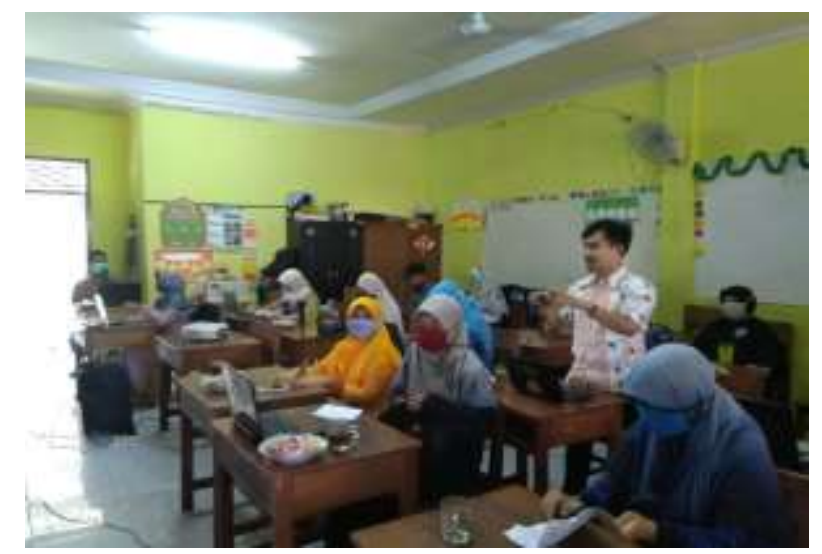

Gambar 2. Pembuatan animasi menggunakan Microsoft PowerPoint

\section{HASIL DAN PEMBAHASAN}

Pemanfaatan media belajar dalam aktifitas kegiatan belajar mengajar sangat membantu para siswa untuk memahami materi yang diajarkan oleh para guru. Selama ini para guru SDIT Al Muhajirin menggunakan metode pengajaran konvensional dengan tidak menggunakan media pembelajaran dan para siswa cenderung kurang aktif dan tidak fokus terhadap materi yang disampaikan oleh para guru. Pelatihan pembuatan media animasi dalam pembelajaran pembelajaran yang diajarkan di sekolah yaitu mata pelajaran Matematika, Bahasa Indonesia, Bahasa Inggris, IPA, IPS, PAI ataupun PKN di SDIT Al Muhajirin ini diharapkan dapat meningkatkan minat belajar siswa untuk belajar mata pelajaran tersebut. Kegiatan pengabdian masyarakat ini Dilaksanakan selama dua hari yaitu Jumat dan Senin tanggal 24 dan 27 Juli 2020 di SDIT Al Muhajirin Cilegon. Kegiatan ini dilaksanakan dalam beberapa tahap sebagai berikut:

Kegiatan 1: Pengenalan Microsoft PowerPoint untuk media pembelajaran

\section{1) Target}

Guru memahami pengertian media pembelajaran dan penggunaanya untuk kegiatan belajar mengajar Indonesia, Bahasa Inggris, IPA, IPS, PAI ataupun PKN. Media pembelajaran adalah alat bantu proses belajar mengajar, yang digunakan untuk menstimulus pikiran, perasaan, perhatian dan kemampuan atau ketrampilan pelajar sehingga dapat mendorong terjadinya proses belajar pada peserta didik. Media pembelajaran juga merupakan bagian tak terpisahkan dari kegiatan pembelajaran di sekolah. Pemanfaatan media pembelajaran merupakan upaya kreatif dan sistematis untuk menciptakan pengalaman yang berkesan dan dapat membantu kelancaran proses belajar siswa.

2) Capaian

Guru memahami semua fitur yang diperlukan untuk dapat membuat media pembelajaran untuk mata pelajaran Matematika, Bahasa Indonesia, Bahasa Inggris, IPA, IPS, PAI ataupun PKN menggunakan program Microsoft PowerPoint.

Kegiatan 2: workshop pembuatan animasi untuk pembelajaran

1) Target

Memberikan pelatihan pembuatan animasi untuk media Matematika, Bahasa Indonesia, Bahasa Inggris, IPA, IPS, PAI ataupun PKN di SDIT Al Muhajirin. Peserta diharapkan menguasai dan menerapkan media pengajaran dengan efek animasi menggunakan Microsoft PowerPoint di masing-masing mata pelajaran yang diajar oleh guru tersebut.

2) Capaian

Penggunaan media pembelajaran atau multimedia adalah seperti berikut, penggunaan bentuk multimedia seperti audio, video, animasi, text, grafik dan image (Jeperson Hutahaean, 
Zulfi Azhar, \& Neni Mulyani, 2020). Proses penyimpan dilakukan secara digital dan memberikan efek animasi. Penggunaan multimedia dengan slide presentasi yang sederhana berformat movie ataupun sound. Pada slide presentasi akan menjadi lebih menarik dengan membuat animasi dengan mengisi gambar ataupun teks. Pada menu "Tab Animations" ambil Grup Menu Animations lalu menu "Custom Animation". Pada menu "Add Effect" untuk penambahan bentuk animasi. Kelompok animasi dasar ada 4 dimana setiap animasi mempunyai beberapa bagian jenis animasi lagi. Secara umum dari sudut pandang perpindahan/transisi antar slide, jenis presentasi dapat dibagi menjadi 2 yaitu: Presentasi Linear dan Presentasi Non Linear (Interaktif) Presentasi linear adalah jenis presentasi yang perpindahan antar slidenya berjalan secara linear dan berurutan, setelah slide 1 ke slide 2 terus ke slide 3 dan begitu seterusnya. Jenis presentasi ini tidak memungkinkan interaksi dengan user (yang melihat presentasi).

Tahapan pelaksanaan kegiatan ini dapat digambarkan dengan langkah-langkah sebagai mana terlihat pada gambar 1. Persiapan meliputi kegiatan mempersiapkan kebutuhan aplikasi office dan animasi pembelajaran di SDIT Al Muhajirin. Ceramah meliputi penjelasan mengenai materi Microsoft word dan powerpoint meliputi Microsoft Office Excel dan Powerpoint meliputi Workbook, Graphics, Data Protection, Data Managemen, Print Data, Using Excel Functions, insert audio dan animasi Powerpoint. Sesi Tanya jawab meliputi kegiatan sharing session. Kegiatan inti adalah praktek yaitu mengimplementasikan materi yang sudah dijelaskan. Kegiatan terakhir adalah pengisian kuesioner dan evaluasi. Adapun aspek penilaian kuesioner dapat dilihat pada tabel 1 .

Tabel 1. Aspek Penilaian Kuesioner

\begin{tabular}{clr}
\hline No & \multicolumn{1}{c}{ Aspek Penilaian } & \multicolumn{1}{c}{ Skor Nilai } \\
\hline 1 & $\begin{array}{l}\text { Kepuasan peserta mengikuti kegiatan Pelatihan } \\
\text { Komputer dan Animasi Pembelajaran }\end{array}$ \\
2 & $\begin{array}{l}\text { Adanya perubahan sikap, pengetahuan dan keterampilan setelah } \\
\text { mengikuti kegiatan Pelatihan Komputer dan Animasi Pembelajaran }\end{array}$ \\
3 & $\begin{array}{l}\text { Pemanfaatan ilmu pengetahuan dan teknologi yang telah } \\
\text { dibagikan untuk peserta secara berkelanjutan }\end{array}$ \\
4 & $\begin{array}{l}\text { Peserta kegiatan dapat mempraktekkan Ilmu pengetahuan dan } \\
\text { teknologi yang di dapat dari kegiatan Pelatihan Komputer dan Animasi }\end{array}$ \\
& $\begin{array}{l}\text { Pembelajaran } \\
\text { Dapat membantu permasalahan yang dimiliki peserta seputar } \\
\text { materi yang diberikan lewat kegiatan Pelatihan Komputer dan Animasi }\end{array}$ \\
& $\begin{array}{l}\text { Pembelajaran } \\
\text { Umpan Balik untuk mengadakan kegiatan Pelatihan } \\
\text { Komputer dan Animasi Pembelajaran kembali }\end{array}$ \\
\hline
\end{tabular}

Interval penilaian kepuasan adalah sebagai berikut :

Indeks $80 \%-100 \%$ : Sangat Puas

Indeks $60 \%-79,99 \%$ : Puas

Indeks 40\% - 59,99\% : Cukup Puas

Indeks 20\% - 39,99\% : Kurang Puas

Indeks $0 \%-19,99 \%$ : Tidak Puas 
Hasil pengisian Kuesioner kepuasan peserta dapat dilihat dari tabel 2 :

Tabel 2. Hasil Kuesioner Kepuasan Peserta

\begin{tabular}{clc}
\hline No & \multicolumn{1}{c}{\begin{tabular}{c}
\multicolumn{1}{c}{ Aspek } \\
Penilaian
\end{tabular}} & $\begin{array}{c}\text { Skor } \\
\text { Nilai }\end{array}$ \\
\hline 1 & $\begin{array}{l}\text { Kepuasan peserta mengikuti kegiatan Pelatihan } \\
\text { Komputer dan Animasi Pembelajaran } \\
2\end{array}$ & $\begin{array}{l}\text { Adanya perubahan sikap, pengetahuan dan } \\
\text { keterampilan setelah mengikuti kegiatan Pelatihan } \\
\text { Komputer dan Animasi Pembelajaran }\end{array}$ \\
3 & $\begin{array}{l}\text { Pemanfaatan ilmu pengetahuan dan teknologi yang } \\
\text { telah dibagikan untuk peserta secara berkelanjutan }\end{array}$ & $87,7 \%$ \\
4 & $\begin{array}{l}\text { Peserta kegiatan dapat mempraktekkan Ilmu } \\
\text { pengetahuan dan teknologi yang di dapat dari } \\
\text { kegiatan Pelatihan Komputer dan Animasi }\end{array}$ & $85,6 \%$ \\
& $\begin{array}{l}\text { Pembelajaran } \\
\text { Dapat membantu permasalahan yang dimiliki } \\
\text { peserta seputar materi yang diberikan lewat } \\
\text { kegiatan Pelatihan Komputer dan Animasi } \\
\text { Pembelajaran }\end{array}$ & $80,2 \%$ \\
6 & $\begin{array}{l}\text { Umpan Balik untuk mengadakan kegiatan Pelatihan } \\
\text { Komputer dan Animasi Pembelajaran kembali }\end{array}$ & $83,6 \%$ \\
\hline
\end{tabular}

Dari tabel 2 diperoleh nilai persentase rata-rata 84,15\%, yang artinya peserta sangat setuju bahwa pelaksanaan Pelatihan Komputer dan Animasi Pembelajaran ini dapat membantu dalam meningkatkan ilmu pengetahuan dan teknologi.

\section{KESIMPULAN}

Dari hasil kegiatan pengabdian kepada masyarakat yang dilakukan di SDIT Al-Muhajirin Cilegon Banten dapat disimpulkan bahwa penilaian kemampuan peserta rata-rata sekitar 84,15\% dan telah menguasai dan memahami materi Microsoft Office dan animasi pembelajaran yang disampaikan dalam kegiatan pengabdian masyarakat tersebut. Materi yang disampaikan kepada peserta terutama guru-guru sudah mencapai semua konsep pada aplikasi animasi, sehingga dalam pembuatan animasi dapat dipahami oleh peserta. Disamping itu peserta juga dapat mengimplementasikan ribbon-ribbon yang ada pada Microsoft PowerPoint dan mampu mengimplementasikan penggunaan animasi dalam pembuatan media pembelajaran yang diinginkan oleh guru.

\section{UCAPAN TERIMA KASIH}

Penulis mengucapkan terima kasih kepada Fakultas Keguruan dan Ilmu Pendidikan Universitas Sultan Ageng Tirtayasa yang telah memberi dukungan financial terhadap pengabdian masyarakat ini.

\section{DAFTAR PUSTAKA}

Ainin, Moh, Mohammad Ahsanuddin, \& Imam Asrori. (2018). Pelatihan Powerpoint Bagi Guru Bahasa Arab MTs Kota Dan Kabupaten Kediri. Jurnal Al-khidmah Vol.1, No.2 : Hal. 74-79

Ardiansah, Feri, \& Diah Rina Miftakhi. (2019). Pelatihan Pembuatan Media Pembelajaran Interaktif Berbasis PowerPoint Bagi Tenaga Pendidik PAUD HIMPAUDI Kecamatan Gabek Kota Pangkalpinang. Jurnal Pengabdian Pada Masyarakat Al Quwwah Vol.2 No.2 : Hal. 108127. 
Elliott, Stephen, N. (2017). Educational Psychology: Effective Theaching, Effective Learning. USA: The Mc. Graw-Hill Companies,Inc.

Hendra, Y.R. (2016). Pelatihan pengembangan media pembelajaran berbasis multimedia untuk meningkatkan kualitas dan kreativitas guru SMA. Jurnal pengabdian masyarakat JDINAMIKA Vol 1 No 1: Hal. 48-52.

Heti Mulyani,Tiawan, Muhammad Nugraha,Muswarman, Halimil Fathi,Muhammad Lulu Latif Usman (2021). Pelatihan Microsoft Office dan Powerpoint Tingkat SMA/SMK Se-Kabupaten Purwakarta, Karawang dan Subang. Jurnal Pengabdian Masyarakat BERNAS Vol.2 No.1 January 2021: Hal. 363-368

Jeperson Hutahaean, Zulfi Azhar, \& Neni Mulyani. (2020). Pelatihan Aplikasi Powerpoint Bagi Guru dan Staf SD Negeri 010240 Pematang Cengkring Jurdimas. Jurnal Pengabdian Kepada Masyarakat Roya. Vol. 3 No. 2: Hal. 147 - 154.

Nurhidayati, Nurhidayati, Imam Asrori, Mohammad Ahsanuddin, \& M. Wahib Dariyadi. (2019). Pembuatan Media Pembelajaran Berbasis Powerpoint dan Pemanfaatan Aplikasi Android Untuk Guru Bahasa Arab. Jurnal KARINOV. Vol. 2 No.3: Hal. 181-184.

Poerwanti, Jenny Indrastoeti S, \& Hasan Mahfud. (2018). Optimalisasi Penggunaan Media Pembelajaran Interaktif Dengan Microsoft Power Point Pada Guru-Guru Sekolah Dasar. JPPM (Jurnal Pengabdian dan Pemberdayaan Masyarakat). Vol. 2 No.2 : Hal 265-271.

Rusli, Muhammad, Edy Winarso, \& Darani Putri. (2020). Pelatihan Microsoft Powerpoint Dasar Bagi Guru Guru Paud Kabupaten Bekasi. Jurnal Pengabdian kepada Masyarakat ABDIMAS. Vol. 1 No.1: Hal. 12-15.

Setiawan, B and Purnomo, E. (2016). Pelatihan Media Pembelajaran Multimedia dengan Powerpoint dan Wondershare Untuk Pengembangan Soft Skills Siswa Bagi Guru SD dan TK. Jurnal Warta LPM Vol.19, No.1 Maret 2016: Hal. 64-73.

Shedriko, Shedriko, Heri Satria Setiawan, and Kusmayadi Kusmayadi. (2018). Pelatihan Perangkat Lunak Powerpoint Untuk Meningkatkan Kinerja Guru Di SD Dan SMP 19 Muhammadiyah Sawangan Depok. Jurnal PkM Pengabdian kepada Masyarakat Vol.01 No.02 Mei-Agustus 2018: Hal. 151-158.

Suntoro, (2021). Pelatihan Pembuatan Blog Pembelajaran Bagi Guru Sekolah Dasar Punna Karya Kabupaten Tangerang. Jurnal Dinamisia Vol. 5, No. 1 Februari 2021: Hal. 47-53. 